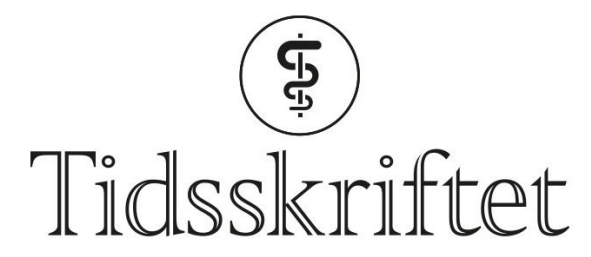

DEN NORSKE LEGEFORENING

\title{
Omgitt av små helter
}

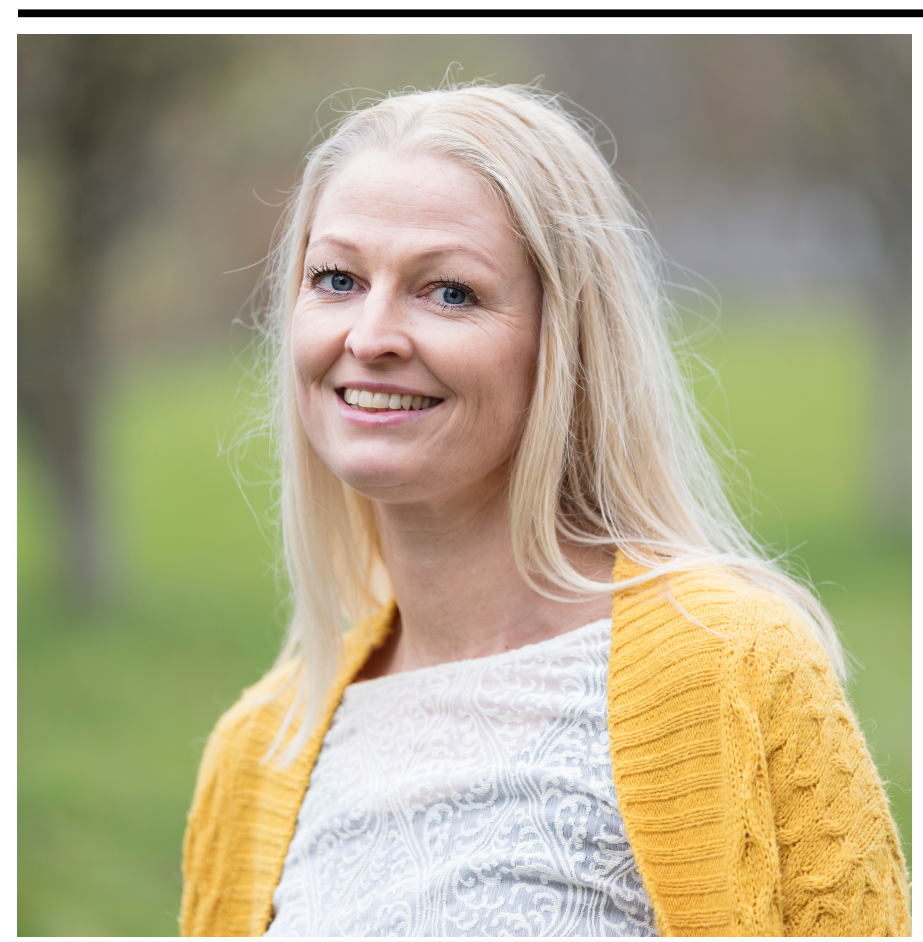

MITT FAGFELT

Anne Kathrine Sebjørnsen er overlege ved Nasjonal behandlingstjeneste for hørsel og psykisk helse ved Oslo universitetssykehus, Ullevål. Hun er spesialist i barne- og ungdomspsykiatri og har tidligere jobbet som fastlege.

- Ja, det finnes et nasjonalt behandlingstilbud innen psykisk helsevern for hørselshemmede! Vi tar imot døve, hørselshemmede, døvblinde og barn av døve foreldre fra hele landet, forteller Sebjørnsen.

Senteret bistår ved besøk på pasientens hjemsted, over telefon eller gjennom videokonferanse. Sebjørnsen forteller at dette er et høyspesialisert og komplekst fagfelt med store utfordringer i forhold til kommunikasjon, men at senteret gir et tilbud med pasientens foretrukne kommunikasjonsform, enten det er norsk tegnspråk, taktilt tegnspråk, norsk talespråk, tegnstøttet tale, skriftlig kommunikasjon, tydelig tale, tegnspråktolk eller ved bruk av tekniske hjelpemidler. 


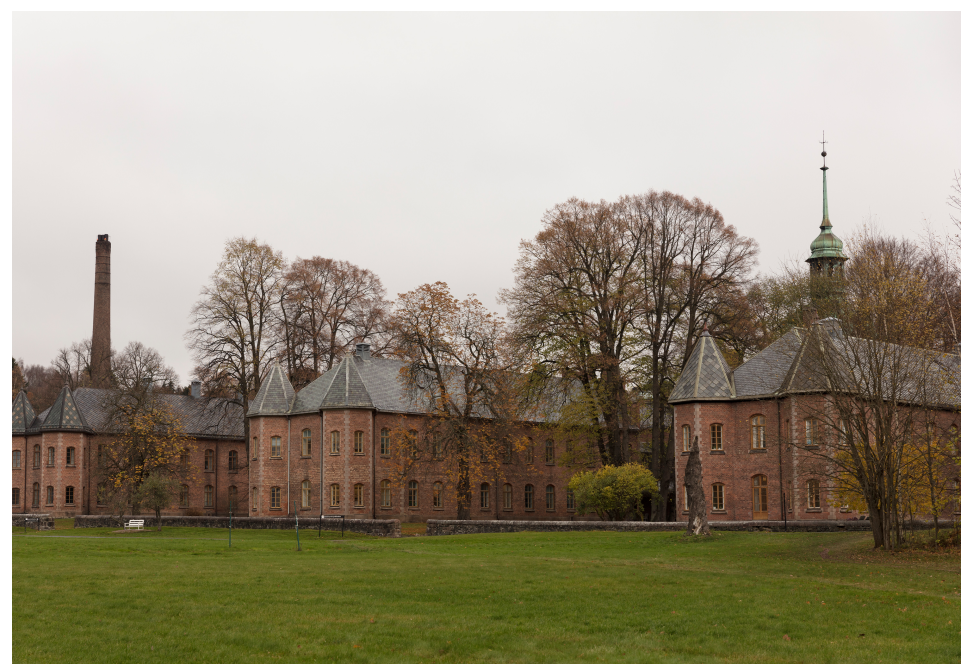

\section{Kan du fortelle om noe viktig som skjer i faget ditt for tiden?}

Faget barne- og ungdomspsykiatri har aldri vært mer spennende enn nå. Vi forstår stadig mer om hva som former menneskehjernen, og fagfelt som genetikk, nevrologi, nevropsykiatri, nevroimmunologi og nevrofysiologi møter nå utviklingspsykologien. Det er spennende og morsomt å forholde seg til så mange fagfelt! Jeg jobber med en pasientgruppe som, i tillegg til hørselsproblematikk og psykiske vansker, kan ha flere somatiske tilstander. Min jobb er å tenke både helhet og detaljer rundt barnets vansker. Er det for dårlig tilrettelagt rundt hørselstapet, blir barnet mobbet, eller har barnet en udiagnostisert genetisk tilstand? Det er så mange faktorer som kan bidra til psykiske vansker, og det er viktig å identifisere dem for å gi riktig hjelp.

Det er litt av et privilegium å få jobbe med disse små heltene som møter hver dag med ekstra bagasje og et utrolig pågangsmot. De gir ikke opp! Det er lett å engasjere seg i barna og ungdommene «våre». 


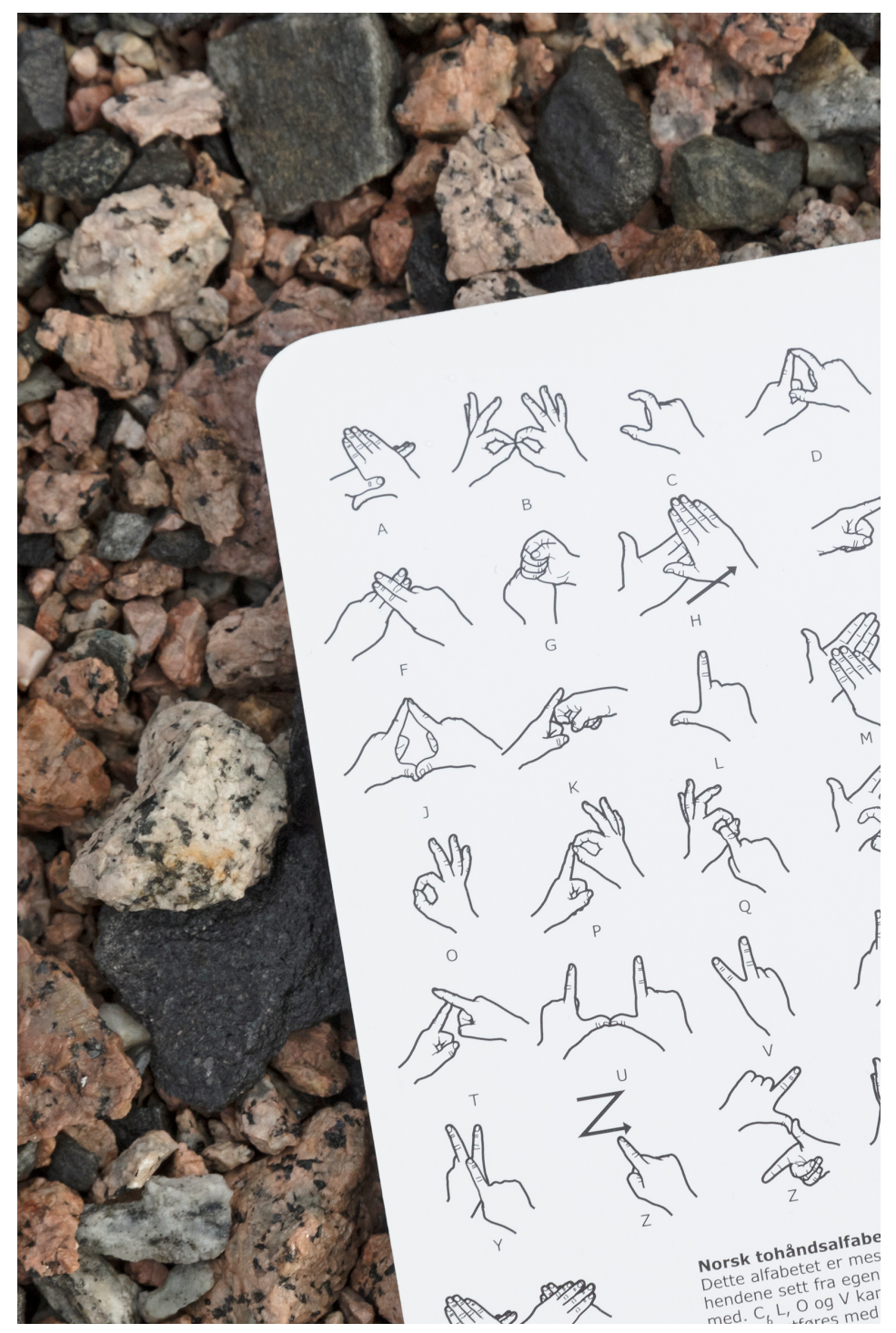

\section{Kan du anbefale en ny og interessant artikkel?}

Vi vet stadig mer om hvordan traumeerfaringer i barndom kan påvirke barns utvikling, ikke bare psykologisk sett, men også rent fysisk. En god oversiktsartikkel er Biological embedding of childhood adversity, som handler om hvordan traumeerfaringer i barndommen kan påvirke hjernens utvikling og forstyrre en rekke fysiologiske mekanismer (1).

\section{Hva er ditt favoritthjelpemiddel på jobb?}

Mitt favoritthjelpemiddel på jobb er YouTube. Jeg jobber blant annet med barn som har opplevd traumer og deres omsorgsgivere, og ser at det er viktig at det skapes en felles forståelse av vanskene. Det finnes gode videoer tilgjengelig fra blant annet Regionalt ressurssenter om vold, traumatisk stress og selvmordsforebygging. Jeg vil anbefale Toleransevinduet av Dag Nordanger, i tillegg til Hvordan traumer former barnehjernen, Reguleringsstøtte, Samregulering og Traumefokusert omsorg. Dette er videoer behandlere kan se sammen med, eller anbefale til, omsorgspersoner og andre instanser som møter barnet eller ungdommen i det daglige. 


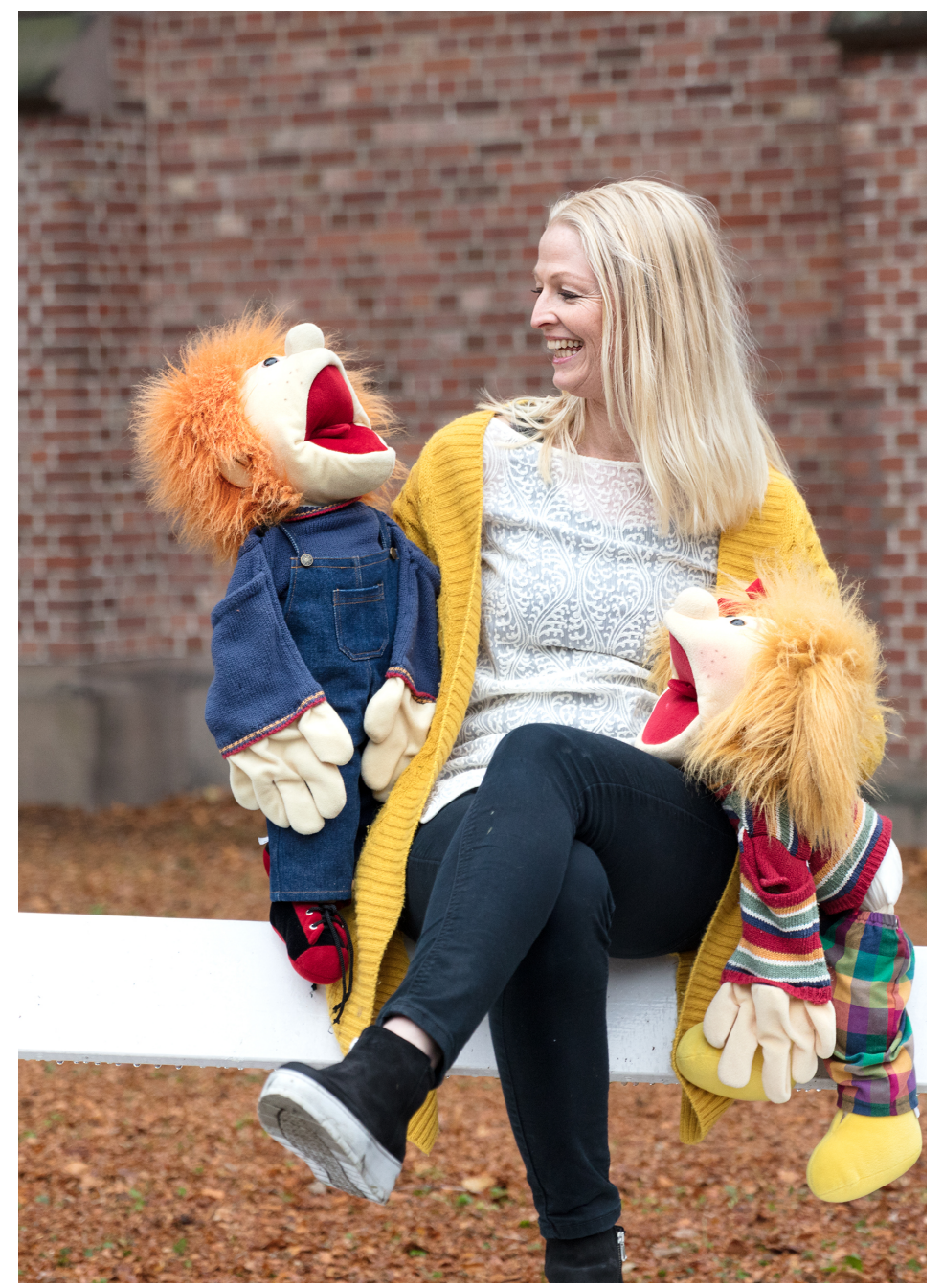

Når man forstår hva som ligger bak utfordrende atferd, bli det lettere å være en god hjelper!

LITTERATUR:

1. Berens AE, Jensen SKG, Nelson CA. Biological embedding of childhood adversity: from physiological mechanisms to clinical implications. BMC Med 2017; 15: 135. [PubMed][CrossRef]

Publisert: 22. januar 2018. Tidsskr Nor Legeforen. DOI:10.4045/tidsskr.17.0971

(C) Tidsskrift for Den norske legeforening 2020. Lastet ned fra tidsskriftet.no 